\title{
Urban-Rural Integration Based on Provincial Spatial Planning in Hainan
}

\author{
Xueqing Chen \\ Institute of Tropical Agriculture and Forestry, Hainan University, Danzhou 571737, China
}

18120250688@163.com

Keywords: Hainan Province; urban-rural integration; spatial planning

\begin{abstract}
China, Hainan Province has distinct advantages in tropical agriculture and tourism. In recent years, China has invested considerable effort in exploring new urban-rural development models in Hainan Province. Based on this, this paper analyzes problems with urban-rural development in Hainan Province and discusses strategies of establishing urban-rural spatial organizations with Hainan characteristics in details. It aims to provide some enlightenment for relevant professionals.
\end{abstract}

\section{Introduction}

Despite the unique tropical agriculture in Hainan Province, per capita net income of local peasants remains low[1]. Due to the outstanding problems with urban-rural dual system and the difficulties in sharing modernization achievements, there has been a growing demand for urban-rural integration in Hainan Province[2]. To realize this objective, this paper carries out specific researches to explore urban-rural integration based on provincial spatial planning in Hainan[3].

\section{Problems with Urban-Rural Development in Hainan Province}

Although Hainan Province has developed rapidly in recent years, it has some problems with urban-rural development, which cannot be neglected. The specific problems are described below.

\subsection{Increasing Income Gaps between Urban and Rural Areas}

In comparison with urban areas, rural areas in Hainan Province have developed much slowly in recent years[4]. According to Table 1, Hainan Province ranked 17th for per capita GDP and 14th for per capita resident income in 2016, thereby becoming the 14th province with the per capita income of more than 20000 Yuan in China. However, disposable income of rural residents in Hainan Province was merely 11843 Yuan. Although it jumped 9.1\% from a year earlier, it was significantly lower than that of urban residents. In other words, there were huge income gaps between urban and rural areas in Hainan Province [1].

Table 1 Ranking of Per Capita GDP and Per Capita Resident Income in China in 2016 (Part)

\begin{tabular}{ccccc}
\hline Province & $\begin{array}{c}\text { Ranking of Per } \\
\text { Capita GDP }\end{array}$ & $\begin{array}{c}\text { Per Capita } \\
\text { GDP/Y }\end{array}$ & $\begin{array}{c}\text { Per Capita } \\
\text { Resident Income/ }\end{array}$ & $\begin{array}{c}\text { Ranking of Per Capita } \\
\text { Resident Income }\end{array}$ \\
\hline Tianjin & 1 & 115612 & 34072 & 4 \\
Beijing & 2 & 114690 & 52530 & 2 \\
Shanghai & 3 & 113731 & 54305 & 1 \\
Hainan & 17 & 44396 & 20653 & 14 \\
Gansu & 31 & 27508 & 14670 & 30 \\
\hline
\end{tabular}

\subsection{Limited Radiation of Central Cities}

In recent years, economy in Hainan Province has shown strong agglomeration tendencies. For example, per capita GDP in Yangpu is 10 times the provincial average and Haikou is superior to other 
regions in Hainan in respect to income and consumption, indicating that central cities of Hainan Province enjoy high primacy ratio. According to the investigation, however, Hainan Province presents weak linkages between central cities, secondary towns and towns of the same level, which eventually leads to the poor radiation effects of central cities.

\subsection{Urgent Need for Transformation and Upgrading}

In Hainan Province, tourism plays an important role in driving local economy, agriculture occupies a prominent position and modern service industry develops slowly, which prompts it to perform optimization, transformation and upgrading. Although Hainan Province has obtained gratifying achievements in this field, challenges brought by agricultural modernization and International Tourist Island construction cannot be neglected.

\section{Strategies of Establishing Urban-Rural Spatial Organizations with Hainan Characteristics}

\subsection{Adhering to the Path of Urbanization with Hainan Characteristics}

According to the evolution characters of urban-rural relations in the United States and Japan in Table 2 and Table 3, urban-rural integration in both countries is significantly based on national conditions. Therefore, this paper proposes to explore an urbanization path with Hainan characteristics and presents specific strategies. (1) Implementing the tourism-led strategy: since tourism concentrates the advantages of Hainan Province, this paper suggests that Hainan Province should adhere to an urbanization path characterized by overall dispersion and local concentration, thereby combining tourism with urbanization and benefiting urban and rural residents. (2) Optimizing urban-rural relations: strained relations between urban and rural areas are not conductive to urban-rural integration in Hainan Province. Therefore, the paper proposes to divide Hainan Province into four regions (east, west, central and north regions) and promote urban-rural integration by region. (3) Strengthening the role of small towns: small towns play a positive role in promoting urban-rural integration in Hainan Province. Hence, it is advised to select (industry-leading, central city-led, agricultural industrialization-leading) development models in accordance with actual conditions of small towns [2].

Table 2 Evolution Characters of Urban-Rural Relations in the United States

\begin{tabular}{|c|c|c|}
\hline Time & $\begin{array}{l}\text { Stage of Urban-Rural } \\
\text { Relations }\end{array}$ & Main Characteristics \\
\hline $1850-1920$ & Primary stage & Population concentration in large cities \\
\hline $1920-1950$ & Middle stage & Central city expansion and suburbanization \\
\hline 1950 - present & Integration stage & $\begin{array}{c}\text { Urban decentralization and population migration to } \\
\text { suburbs }\end{array}$ \\
\hline \multicolumn{3}{|c|}{ Table 3 Evolution Characters of Urban-Rural Relations in Japan } \\
\hline Time & $\begin{array}{r}\text { Stage of } \\
\text { Urban-Rural } \\
\text { Relations } \\
\end{array}$ & Main Characteristics \\
\hline World War II - Early 1960s & Embryonic stage & $\begin{array}{l}\text { Reducing agricultural tax and reforming the farmland } \\
\text { system }\end{array}$ \\
\hline 1960s - present & $\begin{array}{l}\text { Implementation } \\
\text { stage }\end{array}$ & $\begin{array}{l}\text { Enhancing autonomy of rural governments, } \\
\text { implementing agricultural protection policy and narrowing } \\
\text { gaps between urban and rural areas }\end{array}$ \\
\hline
\end{tabular}

\subsection{Organizing Life Circles that Meet Basic Public Service Needs and Serve International Tourism Island Construction}

According to the five national comprehensive development plans of Japan, this paper suggests that Hainan Province should organize scientific and practical life circles on the basis of activity-oriented spatial planning units. Life circles here consist of two parts, namely, urban life circles and basic life 
circles. Table 4 intuitively demonstrates organization schemes for the two kinds of life circles.

Table 4 Organization Schemes for the Two Kinds of Life Circles

\begin{tabular}{|c|c|c|}
\hline $\begin{array}{l}\text { Type of Life } \\
\text { Circles }\end{array}$ & Quantity & Characteristics \\
\hline $\begin{array}{l}\text { Urban Life } \\
\text { Circle }\end{array}$ & 4 & $\begin{array}{c}\text { The four urban life circles are centered on Haikou, Sanya, Qionghai and } \\
\text { Danzhou respectively, with the commuting time of } 1.5 \text { to } 2 \text { hours. Wherein, } \\
\text { urban life circles in Haikou, Sanya and Qionghai should support premium } \\
\text { service networks for the international tourism island while the urban life } \\
\text { circle in Danzhou should build high-tech, modern manufacturing and } \\
\text { international tourism service systems. }\end{array}$ \\
\hline $\begin{array}{l}\text { Basic Life } \\
\text { Circle }\end{array}$ & 21 & $\begin{array}{l}\text { Basic life circles take towns as the minimum space units, with the } \\
\text { commuting time of } 30 \text { to } 40 \text { minutes. Although they are basically consistent } \\
\text { with administrative boundaries of counties and municipalities, two basic } \\
\text { circles need be organized in Wenchang, Ledong and Danzhou respectively. }\end{array}$ \\
\hline
\end{tabular}

\subsection{Organizing a Spatial Structure with Four Cores, Multiple Corridors and Flat Networks}

Based on the development experience of Jeju Island, Hawaii, Taiwan and Singapore, this paper suggests that Hainan Province should organize a spatial structure of four cores, multiple corridors and flat networks. The spatial structure is mainly composed of four cores, multiple centers, numerous township service centers and urban-rural interaction function networks. (1) Four cores: it is advised to guide the various urban-rural development factors by cultivating four core cities and construct the four cores on the basis of urban life circles. (2) Multiple centers: in the process of developing medium-sized cities with regional center roles, the various elements should be concentrated in regional centers. (3) Numerous township service centers: it should adhere to the urbanization path characterized by overall dispersion and local concentration to promote the construction of township service centers. (4) Urban-rural interaction function networks: it is feasible to promote the construction of function networks from the perspective of agricultural production, service support and tourism development. (5) Multiple corridors: according to the national comprehensive development plans of Taiwan, Hainan Province should implement corridor-oriented development and perform functions of the four core cities. In that case, ecological corridors like Zhubijiang Ecological Corridor and Huishan-Liulianling Ecological Corridor shall be constructed.

\section{Conclusions}

To sum up, urban-rural integration based on provincial spatial planning directly influences long-term development of Hainan. On this basis, this paper presents concrete recommendations (adhere to the urbanization path with Hainan characteristics and organize a spatial structure with four cores, multiple corridors and flat networks), which demonstrates the practical value of the research. It provides certain reference for theoretical researches and practical explorations in related fields.

\section{References}

[1] Li F, Li W, Zhen L, et al. Estimating Eco-Compensation Requirements for Forest Ecosystem Conservation A Case Study in Hainan Province, Southern China[J]. Outlook on Agriculture, 2011, 40(1):51-57.

[2] Andersson K, Angelstam P, Elbakidze M, et al. Green infrastructures and intensive forestry: need and opportunity for spatial planning in a Swedish rural-urban gradient.[J]. Scandinavian Journal of Forest Research, 2013, 28(2):143-165.

[3] Shaowei Chen, Jinrong Jiang. The Relationship of Financial Development, Urbanization and Urban-Rural Income Gap: An Empirical Research Based on Provincial Panel Data in China[J]. Biochemical and Biophysical Research Communications, 2014, 6(3):1228-1233.

[4] Zhang Y L, Li J, Zhang G, et al. Radiocarbon-based source apportionment of carbonaceous aerosols at a regional background site on Hainan Island, South China.[J]. Environmental Science \& Technology, 2014, 48(5):2651-9. 